\title{
Investments In Consumer Relationships - A Critical Reassessment And Model Extension
}

Citation for published version (APA):

de Wulf, K., Odekerken-Schröder, G. J., \& van Kenhove, P. (2002). Investments In Consumer

Relationships - A Critical Reassessment And Model Extension. METEOR, Maastricht University School of Business and Economics. METEOR Research Memorandum No. 077

https://doi.org/10.26481/umamet.2002077

Document status and date:

Published: 01/01/2002

DOI:

10.26481/umamet.2002077

Document Version:

Publisher's PDF, also known as Version of record

\section{Please check the document version of this publication:}

- A submitted manuscript is the version of the article upon submission and before peer-review. There can be important differences between the submitted version and the official published version of record.

People interested in the research are advised to contact the author for the final version of the publication, or visit the DOI to the publisher's website.

- The final author version and the galley proof are versions of the publication after peer review.

- The final published version features the final layout of the paper including the volume, issue and page numbers.

Link to publication

\footnotetext{
General rights rights.

- You may freely distribute the URL identifying the publication in the public portal. please follow below link for the End User Agreement:

www.umlib.nl/taverne-license

Take down policy

If you believe that this document breaches copyright please contact us at:

repository@maastrichtuniversity.nl

providing details and we will investigate your claim.
}

Copyright and moral rights for the publications made accessible in the public portal are retained by the authors and/or other copyright owners and it is a condition of accessing publications that users recognise and abide by the legal requirements associated with these

- Users may download and print one copy of any publication from the public portal for the purpose of private study or research.

- You may not further distribute the material or use it for any profit-making activity or commercial gain

If the publication is distributed under the terms of Article $25 \mathrm{fa}$ of the Dutch Copyright Act, indicated by the "Taverne" license above, 


\section{INVESTMENTS IN CONSUMER RELATIONSHIPS \\ A CRITICAL REASSESSMENT AND MODEL EXTENSION}

Kristof De Wulf, Assistant Professor in Marketing at the Vlerick Leuven Gent Management School and at Ghent University, Bellevue 6, 9050 Ledeberg (Gent), Belgium, tel: +32 9 2109863, fax: +329 2109875, e-mail: kristof.dewulf@vlerick.be

Gaby Odekerken-Schröder (corresponding author), Associate Professor in Marketing at the Faculty of Economics and Business Administration, Maastricht University, P.O. Box 616, 6200 MD Maastricht, the Netherlands, tel: +31 43 3883618, fax: +31 43 3884918, e-mail: g.schroder@mw.unimaas.nl

Patrick Van Kenhove, Associate Professor in Marketing at the Faculty of Economics and Business Administration, Ghent University, Hoveniersberg 25, 9000 Gent, Belgium, tel: +32 9 2643526, fax: +32 9 2644279, e-mail: patrick.vankenhove@rug.ac.be

Acknowledgement: The authors gratefully acknowledge the contribution of Filip De Boeck and the cooperation with and support of a large Belgian apparel retail chain. 


\title{
INVESTMENTS IN CONSUMER RELATIONSHIPS \\ A CRITICAL REASSESSMENT AND MODEL EXTENSION
}

\begin{abstract}
This study is a critical reassessment and extension of De Wulf, Odekerken-Schröder, and Iacobucci's (2001) framework investigating retail investments in consumer relationships. Their initial model relates four types of relationship marketing efforts to perceived relationship investment, in turn influencing relationship quality and ultimately behavioral loyalty. Based upon signaling theory, we extend this model by introducing product and service efforts as additional antecedents. Moreover, in contrast to the use of self-reported measures in the initial model, we apply customer database information in order to measure the construct of behavioral loyalty. Based upon 187 consumers reporting on their relationship with a Belgian apparel retailer, the SEM results provide guidelines for retailers how to increase the quality of their relationships with consumers by strengthening consumers' perceptions of relationship investment.
\end{abstract}

Keywords: retail, consumer relationships, relationship quality, loyalty, SEM 
De Wulf, Odekerken-Schröder, and Iacobucci (2001) recently developed and tested a model investigating the role of four different relationship marketing tactics in strengthening retailerconsumer relationships: direct mail, preferential treatment, interpersonal communication, and tangible rewards. Their results indicated that these relationship marketing tactics play a differential, yet consistently positive role in affecting perceived relationship investment, ultimately influencing relationship quality and behavioral loyalty. While their study was an interesting first attempt to empirically assess the effect of different relationship marketing tactics in a retail context, they stressed the need for future research to overcome two major shortcomings. First, additional tangible elements in the retail mix such as product price, product quality, and service quality should be added as additional antecedents of relationship investment in order to be able to better capture the mechanisms behind the establishment of strong retailerconsumer relationships. For example, while the SERVQUAL measures (Parasuraman, Zeithaml, and Berry $1988 ; 1991)$ can be applied to a broad spectrum of contexts, no previous research of which we are aware has examined their effects on the relationship outcomes examined in this study. Second, De Wulf, Odekerken-Schröder, and Iacobucci's (2001) study potentially suffered from the fact that the true meaning of behavioral loyalty may only be partially captured given that its measure was based on self-reports. Confidence in their results could be strengthened with access to behavioral data on customer purchase histories that are not subject to potential recall loss, enabling the investigation of longer strings of purchases.

In response to their suggestions for future research, the objective of our study is to extend their model by adding product quality, product price, and service quality as potential additional antecedents of relationship investment. In other words, we want to investigate whether a positive 
retail experience is a requirement for effective relationship marketing. Several authors recognize the importance of product efforts (Anderson and Sullivan 1990; Metcalf, Frear, and Krishnan 1990), service efforts (Boulding et al. 1993; Parasuraman, Zeithaml, and Berry 1994), as well as relationship marketing efforts (Dwyer, Schurr, and Oh 1987; Ganesan 1994; Gwinner, Gremler, and Bitner 1998) in building customer relationships. However, to the best of our knowledge, no previous research considered all of these efforts simultaneously. By incorporating all three types of efforts in one integrated model, we can assess their differential impact in a more reliable way as opposed to testing their effects separately. Moreover, this study uses multiple methods relating behavioral data originating from a customer database to attitudinal data resulting from a customer survey. Most studies confine to using only one data source, causing potential problems of common method bias. Finally, while external validity was emphasized in the initial study by having consumers report on a large variety of retailers, this study focuses on internal validity as 187 consumers reported on the relationship they have with one particular retailer. This should strengthen our confidence in the internal validity of the results.

First, we discuss a theoretical framework, signaling theory, justifying the inclusion of additional antecedents of perceived relationship investment, resulting in an extended conceptual model. After presenting the constructs incorporated in this model and the arguments underlying our research hypotheses, we elaborate upon the research design of the study. Finally, we present and discuss the results and their implications for retailing practice. 


\section{THEORETICAL BACKGROUND}

The original study departed from a reciprocity perspective as a justification for the tested conceptual model. Reciprocal action theory states that actions taken by one party in an exchange relationship are reciprocated by the other party, resulting from anticipating feelings of guilt a party would have, should it violate the norm of reciprocity (Li and Dant 1997). De Wulf, Odekerken-Schröder, and Iacobucci (2001, p. 34) apply this reasoning to retailer-consumer relationships as follows: "The idea behind our model is consistent with Blau (1964) who already recognized that an investment of time, effort, and other irrecoverable resources in a relationship creates psychological ties that motivate parties to maintain the relationship and sets an expectation of reciprocation. We apply this principle in a consumer context, representing a retailer's irrecoverable resources by the construct of 'perceived relationship investment'. The resulting constructs of 'relationship quality' and 'behavioral loyalty', embodying consumers' reciprocation of a retailer's investments, reflect the extent to which consumers want to maintain their relationship."

Complementary to the reciprocity principle, signaling theory, emerging from the study of information economics, can make a valuable contribution to understanding the development and sustainability of long-term relationships. In order to stimulate reciprocation, signals need to be sent out that inform the other party about its unobservable intentions (Boulding and Kirmani 1993). One of the basic assumptions of signaling theory is that different exchange parties possess different amounts of information, affecting the nature of their mutual relationship. For example, consumers often have no prior information as to the reliability of a product before it is used. This 
information asymmetry problem is being reduced when signals representing 'missing' information are transferred from one party to another (Boulding and Kirmani 1993; Kirmani and Rao 2000). Sticking to the same example, a signal conveyed by a manufacturer might be the warranties offered on his products, providing the customer with an indication of the product reliability level to be expected.

The relationship marketing efforts distinguished by De Wulf, Odekerken-Schröder, and Iacobucci (2001) can easily be interpreted as signals meant to inform customers about the retailer's unobservable relationship investment. For example, offering travelers frequent flier miles can be considered as a signal that the airline carrier wants to build long-term relationships with its customers. However, in the Belgian apparel sample of their original study, only 31 percent of the variance in perceived relationship investment could be explained by the four relationship marketing efforts included. This instills our confidence that additional contributing factors or signals exist that boost consumers' perceptions of relationship investment by the retailer. While several types of marketing signals have received considerable empirical attention such as advertising (e.g., Kirmani 1997), branding (e.g., Rao, Qu, and Ruekert 1999), and pricing (e.g., Dawar and Sarvary 1997), product and service elements remained largely unexplored as signals. In response to this, the current study investigates these two categories of signals in addition to relationship marketing efforts. This fulfills a need recognized by Kirmani and Rao (2000) to conduct empirical research on signals that have traditionally been neglected such as instore decoration and the quality of salespeople. Simultaneously, our study fits in with their perceived need to explore consumer responses to multiple signals as opposed to one category of signals only. 
By integrating both theoretical frameworks, we propose the conceptual model depicted in Figure 1.

---- Insert Figure 1 about here ----

\section{CONCEPTUAL MODEL AND RESEARCH HYPOTHESES}

Below, we discuss each of the constructs included in the model and provide support for the hypotheses concerning their interrelationships.

Perceived Relationship Investment

The focal construct in our conceptual model is perceived relationship investment. In line with De Wulf, Odekerken-Schröder, and Iacobucci (2001), we define perceived relationship investment as a consumer's perception of the extent to which a retailer devotes resources, efforts, and attention aimed at maintaining or enhancing relationships with regular customers that do not have outside value and cannot be recovered if these relationships are terminated.

In the following sections, we discuss the antecedents and consequences of perceived relationship investment. Figure 1 shows that we distinguish three types of signals underlying perceived relationship investment: product efforts (product price and product quality), service efforts (reliability, responsiveness, assurance, empathy, and tangibles), and relationship marketing efforts (direct mail, interpersonal communication, preferential treatment, and tangible rewards). In addition, we elaborate upon relationship quality and behavioral loyalty as reciprocal consequences of perceived relationship investment. 
Product Efforts as Signals of Perceived Relationship Investment

Corstjens and Lal (2000) indicated that buyers of consumer goods can be characterized by the heterogeneity in their trade-offs between price and quality. According to them, a quality segment, deriving greater utility from perceived quality, and a price segment, driven by low prices, can invariably be distinguished. Therefore, we investigated both types of product efforts separately in our study.

Product price. Concurrent with Dabholkar, Thorpe, and Rentz (1996), we view product price as an important determinant of store loyalty, being distinct from service quality. We define product price as a consumer's perception of the extent to which the merchandise selection offered by a retailer is expensive (Dodds, Monroe, and Grewal 1991). In other words, price refers to what is given up or sacrificed in exchange for a product (Ahtola 1984; Monroe and Krishnan 1985). We consider product price as a signal of perceived relationship investment as, by asking a low price, consumers might assume that the retailer is apparently willing to forgo short-term profits in return for customer loyalty. Consequently, we propose the following hypothesis:

$\mathrm{H}_{1}$ : A lower perceived level of product price leads to a higher perceived level of relationship investment

Product quality. In line with Finn and Kayandé (1997), we argue that product quality is an essential part of the retail experience. We define product quality as a consumer's level of satisfaction with the merchandise selection offered by a retailer (Gaski and Etzel 1986; McDaniel and Burnett 1990). A high level of product quality is generally considered to make consumers feel excited, pleased, content, satisfied, and committed. Finding high-quality products 
that suit a person's needs often engender feelings of contentment and pride (Yoo, Park, and MacInnis 1998). However, for a store to carry high quality products, it may be required to make costly arrangements with suppliers, to incur higher product inspection costs, or to make other tangible investments (Garvin 1984). Such signals involve up-front expenditures that are expected to be recovered in the future by the benefits of strengthened relationships. By consequence, such expenditures might stimulate consumers' confidence that the retailer is willing to make investments in their mutual relationship. Hence, we hypothesize:

$\mathrm{H}_{2}$ : A higher perceived level of product quality leads to a higher perceived level of relationship investment

Service Efforts as Signals of Perceived Relationship Investment

Conceptually, we define service quality as a consumer's perception of the extent to which the service offered by a retailer is superior or excellent (Parasuraman, Zeithaml, and Berry 1988). Taking five dimensions as a basis (i.e., reliability, responsiveness, assurance, empathy, and tangibles), Parasuraman, Zeithaml, and Berry $(1988 ; 1991)$ developed a 22-item SERVQUAL scale, which has been tested and/or adapted in various settings. Tangibles refer to physical facilities, equipment, and appearance of personnel. Reliability is defined as the ability to perform the promised service dependably and accurately. Responsiveness means the willingness to help customers and provide prompt service. Assurance is the knowledge and courtesy of employees and their ability to inspire trust and confidence. Finally, empathy is considered to be the caring and individualized attention the firm provides its customers with.

As several authors advocate to consider service quality as an umbrella construct with distinct dimensions, we consider retail service quality as a second order-factor (e.g., Babakus and 
Boller 1992; Cronin and Taylor 1992; Dabholkar, Thorpe, and Rentz 1996). Moreover, as marketing literature offers considerable support for the superiority of simple performance based measures of service quality (e.g., Bolton and Drew 1991; Churchill and Surprenant 1982), we only used perception scores to measure service quality.

Retail stores need to make upfront expenditures of money in order to establish an adequate level of service quality. For instance, they need to invest in the training and empowerment of store personnel, infrastructure and interior design, and policies and procedures. The fundamental rationale underlying these investments in service quality is that the retailer spends money now expecting to recover it in the future. As consumers might consider such investments as true efforts of the retailer to enhance customer loyalty, we hypothesize the following:

$\mathrm{H}_{3}$ : A higher perceived level of service quality leads to a higher perceived level of relationship investment

Relationship Marketing Efforts as Signals of Perceived Relationship Investment

Direct mail. We consider direct mail as a consumer's perception of the extent to which a retailer keeps its regular customers informed through direct mail. By conveying interest in the consumer, communication is often considered to be a necessary condition for the existence of a relationship (Crosby and Stephens 1987). Hence, we hypothesize:

$\mathrm{H}_{4}$ : A higher perceived level of direct mail leads to a higher perceived level of relationship investment

Preferential treatment. Preferential treatment refers to a consumer's perception of the extent to which a retailer treats and serves its regular customers better than its non-regular 
customers. According to Peterson (1995), such distinctive treatment enables a retailer to address a consumer's basic need to feel important. Accordingly, we hypothesize:

$\mathrm{H}_{5}$ : A higher perceived level of preferential treatment leads to a higher perceived level of relationship investment

Interpersonal communication. We regard interpersonal communication as a consumer's perception of the extent to which a retailer interacts with its regular customers in a warm and personal way. Social interaction and personal exchanges between customers and retailers have regularly been shown to influence relationship outcomes (Evans, Christiansen, and Gill 1996; Mittal and Lassar 1996). As a result, we hypothesize:

$\mathrm{H}_{6}$ : A higher perceived level of interpersonal communication leads to a higher perceived level of relationship investment

Tangible rewards. We define tangible rewards as a consumer's perception of the extent to which a retailer offers tangible benefits such as pricing or gift incentives to its regular customers in return for their loyalty. Tangible rewards are often considered to help customers remain loyal (Peterson 1995; Sharp and Sharp 1997). Therefore, we hypothesize:

$\mathrm{H}_{7}$ : A higher perceived level of tangible rewards leads to a higher perceived level of relationship investment

Relationship Quality as a Reciprocation of Perceived Relationship Investment Consistent with other studies on relationship marketing (e.g., Kumar, Scheer, and Steenkamp 1995), we included relationship quality, defined as an overall assessment of the strength of a relationship (Garbarino and Johnson 1999; Smith 1998), as a reciprocal outcome. Previous research conceptualized relationship quality as a higher-order construct consisting of 
several distinct, although related, dimensions (e.g., Bejou, Wray, and Ingram 1996; Dorsch, Swanson, and Kelley 1998). In line with De Wulf, Odekerken-Schröder, and Iacobucci (2001), we consider relationship quality as encompassing relationship satisfaction, trust, and relationship commitment, implying that a better quality relationship is accompanied by a greater level of satisfaction, trust, and commitment. While these attitudinal constructs may be conceptually distinct, consumers have difficulty making fine distinctions between them and tend to lump them together (Crosby, Evans, and Cowles 1990).

As we intend to replicate De Wulf, Odekerken-Schröder, and Iacobucci's (2001) study, we applied identical definitions and measures for each of the subdimensions of relationship quality. We define relationship satisfaction as a consumer's affective state resulting from an overall appraisal of his relationship with a retailer, trust as a consumer's confident belief in a retailer's honesty towards this consumer, and relationship commitment as a consumer's enduring desire to continue a relationship with a retailer accompanied by this consumer's willingness to make efforts at maintaining it.

$\mathrm{H}_{8}$ : A higher perceived level of relationship investment leads to a higher perceived level of relationship quality

\section{Does Behavior Follow Attitude?}

In general, most studies on relationship marketing have confined themselves to reporting perceptual data only. Hardly any study has investigated the relationship between perception and action measures (Pritchard, Havitz, and Howard 1999; Storbacka, Strandvik, and Grönroos 1994). In response, we not only evaluate whether perceived relationship investment is reciprocated in terms of enhanced relationship quality, but also in terms of behavioral loyalty 
measured on basis of actual purchase data. In line with the literature on RFM segmentation (Colombo and Jiang 1999), we included behavioral loyalty as a composite of purchase recency (time elapsed since the last purchase), purchase frequency, and monetary value (the average amount of money spent per purchase). We investigate the following hypothesis:

$\mathrm{H}_{9}$ : A higher level of relationship quality leads to a higher level of behavioral loyalty

\section{METHOD}

Sample and Procedure

We selected 930 customers of a large Belgian clothing retailer's customer database. We calculated a specific 'RFM' score per customer as a composite measure of the recency, frequency, and monetary value of his former purchases. We distinguished two recency categories depending upon whether a customer made a purchase during the last season (last six months) or whether the last purchase occurred at least two seasons ago. Frequency was calculated as the number of purchases during the last five seasons. Monetary value referred to the average amount of money spent per purchase during the last five seasons. Care was taken that customers with high, medium, and low RFM scores were equally represented in the sample and that each of these three categories was comparable in terms of age and gender composition.

We sent a mail survey to all customers selected from the database, asking them to provide their perceptions on their relationship with the retailer, comprising all constructs examined in our study. In order to increase response rates, we rewarded all respondents who provided name and address information with a lottery ticket. Moreover, it simultaneously enabled us to link the perceptual data included in the survey with the database information residing in the retailer's 
customer database. Nevertheless, we guaranteed anonymity to potential respondents as we used the data only on an aggregate level. After a period of two weeks, 192 respondents (21 percent response rate) returned the completed questionnaire. A follow-up by telephone among nonrespondents increased the total response to 323 (35 percent response rate). After removing those respondents from the sample who did not complete all questions or did not provide name and address information, we retained 187 usable responses (20 percent response rate) for data analysis. We detected no significant differences in the means of the constructs between those cases retained and those removed.

\section{Measures}

With respect to the replication part of the model, all measures were identical to the original study of De Wulf, Odekerken-Schröder, and Iacobucci (2001). The constructs that we added to the model were based upon established measures: product price (Dodds, Monroe, and Grewal 1991), product quality (Gaski and Etzel 1986), and service quality (Parasurman, Zeithaml, and Berry 1994).

\section{RESULTS}

Overall Model Evaluation

While the chi-square value is significant (619.75 with 348 degrees of freedom), the ratio of chi-square to degrees of freedom is 1.78 , which can be considered as adequate. Although the values of GFI (.81) and AGFI (.77) are somewhat lower than those of NNFI (.90) and CFI (.91), this result is mainly due to the former measures being more easily affected by model complexity. 
In general, the indicated fits are good, including RMSEA, which is .065, and SRMR, being .071. Given the adequacy of these indices, given the fact that the model was developed on theoretical bases, and given the relative complexity of the model, no model respecifications were made.

\section{Measurement Model Evaluation}

In order to assess whether relationship quality can be regarded as a higher-order construct, we first factor-analyzed the multi-item scales separately for relationship satisfaction, trust, and relationship commitment. A single factor emerged for each scale and reliability was uniformly high for all three constructs (Cronbach alpha of respectively .85, .88, and .75). Next, we estimated the second-order factor model with the first-order factors (relationship satisfaction, trust, and relationship commitment) originating from the higher-order factor 'relationship quality'. CFI and NNFI indices were .94 and .92 respectively, indicating adequate fit. Moreover, convergent validity was supported as all first-order and second-order factor loadings were significant. As a result, we calculated averages for relationship satisfaction, trust, and relationship commitment based upon the three items of each construct and used these averages as indicators of the construct relationship quality.

The same procedure was followed in order to assess whether service quality can be modeled as a second-order factor. Cronbach alpha values for the constructs of reliability (.87), responsiveness (.86), assurance (.82), empathy (.79), and tangibles (.88) again were satisfactory. The measurement results for the second-order factor model relating service quality to its five underlying dimensions were acceptable as CFI and NNFI indices were .88 and .87 respectively.

Table 2 reports the results of the measurement model. We assessed the quality of our measurement efforts by investigating unidimensionality, convergent validity, reliability, and 
discriminant validity. Evidence for the unidimensionality of each construct included appropriate items loading at least .65 on their respective hypothesized component, with a loading no larger than .30 on other components in a principal components analysis. In addition, the overall goodness of fit supports unidimensionality (Steenkamp and van Trijp 1991). Convergent validity was supported by all loadings being significant $(\mathrm{p}<.01)$ and nearly all $\mathrm{R}^{2}$ exceeding .50 (Hildebrandt 1987). Reliability was assessed jointly for all items of a construct by computing the composite reliability and average variance extracted (Baumgartner and Homburg 1996;

Steenkamp and van Trijp 1991). All scales demonstrate excellent composite reliabilities above 90. Discriminant validity was tested based upon Fornell and Larcker's (1981) procedure. This test suggests that a scale possesses discriminant validity if the average variance extracted by the underlying construct is larger than the shared variance (i.e. the squared intercorrelation) with other latent constructs. As the average variance extracted was at least .78, we found strong evidence for discriminant validity between each possible pair of latent constructs.

---Insert Table 2 about here---

Structural Model Evaluation

Table 3 indicates that all significant relationships between latent constructs are in the hypothesized direction, providing initial evidence for our conceptual model and supporting the nomological validity of the constructs. No empirical evidence was found for the hypothesized relationship from product price $\left(\mathrm{H}_{1}\right)$ and product quality $\left(\mathrm{H}_{2}\right)$ to perceived relationship investment, suggesting that consumers do not perceive these elements to be signals of relationship investment. Contrary to these findings, service quality reveals a strong positive impact on perceived relationship investment, providing support for $\mathrm{H}_{3}$. With respect to the 
relationship marketing efforts, we found support for the fact that direct mail $\left(\mathrm{H}_{4}\right)$, interpersonal communication $\left(\mathrm{H}_{6}\right)$, tangible rewards $\left(\mathrm{H}_{7}\right)$ acted as signals of perceived relationship investment. Only for preferential treatment $\left(\mathrm{H}_{5}\right)$, no significant relationship with perceived relationship investment could be found. The fact that consumers perceived the retailer to make investments in their mutual relationship was convincingly reciprocated in terms of increased relationship quality, supporting $\mathrm{H}_{8}$. Finally, we could not find support for the hypothesis that higher levels of relationship quality lead to more loyal behavior $\left(\mathrm{H}_{9}\right)$.

---Insert Table 3 about here---

\section{DISCUSSION AND MANAGERIAL IMPLICATIONS}

First, our findings indicate that product price and quality did not qualify as signals of perceived relationship investment. Two possible explanations could underlie this conclusion. A first reason for this finding could be that consumers interpret attractive levels of product price and quality only as minimal conditions for them to be willing to make a purchase at a store. By consequence, they apparently do not consider both efforts as an investment on behalf of the store in a long-term relationship with them. An alternative explanation could simply be that product price and quality are efforts that are not specifically targeted at particular consumers. Prices and quality levels of apparel in a store are the same for all customers, thus limiting their role as signals of relationship investment. This explanation is in line with social comparison theory (Festinger 1954, p. 127) stating that each individual wishes to be slightly better than the others with whom he compares himself. In case a consumer perceives efforts to be equal to all consumers, which is the case for product price and quality, this consumer does not feel "being 
better than others". This could be an encouraging finding for all retailers that are undertaking efforts to customize their product offerings such as Levi's does with its custom made jeans. By doing this, they might be able to influence perceptions of relationship investment beyond generating mere transaction satisfaction.

Rust, Zahorik, and Keiningham (1995) introduced their "return on quality" approach aimed at enabling managers to determine where to spend on service quality, how much to spend, and the likely financial impact from service expenditures. While our approach is not of a financial nature, we consider it as complementary to theirs in the sense that we empirically assess to which extent service expenditures are considered as true investments from the viewpoint of the consumer. As the increase in explained variance of perceived relationship investment from .31 to .77 can mainly be attributed to the inclusion of the service quality construct, we clearly demonstrate that consumers indeed recognize service quality to be a strong signal of perceived relationship investment. While service quality has been shown to lead to increased satisfaction with a transaction (e.g., Parasuraman, Zeithaml, and Berry 1994; Woodside, Frey, and Daly 1989), we empirically supported that service quality is also a strong precursor of a more longterm construct such as perceived relationship investment. By consequence, these results should provide retailers with enough confidence that the upfront investments in service quality enhancement will be transformed into strengthened perceptions of relationship investment and, as a result, in stronger relationships.

When looking at the results related to the relationship marketing efforts, only preferential treatment did not act as a signal of perceived relationship investment. This result is partially in line with what De Wulf, Odekerken-Schröder, and Iacobucci (2001) found in their discussion of the Belgian apparel sample. Just as in the original study, interpersonal communication and direct 
mail were important antecedents of relationship investment. However, in the current study tangible rewards also revealed a significant relationship with perceived relationship investment, while it did not in the original study. The opposite was found for the construct of preferential treatment. The reason for these differences might reside in the fact that customer groups of different retailers hold different expectations in terms of receiving relationship marketing tactics. Despite the earlier mentioned concerns to using expectation scores, this finding might stress the need to collect this type of information in order to enhance the comparability of findings. Moreover, it would enable retailers to refine the segmentation of their target market, ultimately better responding to their specific needs and wants.

Finally, as in the original study, reciprocal action theory was supported as better perceptions of relationship investment led to enhanced relationship quality. However, behavioral loyalty (based upon customer database information) was not affected by relationship quality in this study, while self-reported measures of behavioral loyalty in the original study were consistently influenced by relationship quality. First, this underlines the potential danger of only using one data source in empirical studies, potentially leading to common method bias. Second, in line with Dick and Basu (1994), our results implied that respondents were more or less evenly spread across four different loyalty segments: high relationship quality - high behavioral loyalty ("true loyalty"), high relationship quality - low behavioral loyalty ("latent loyalty"), low relationship quality - high behavioral loyalty ("spurious loyalty"), and low relationship quality low behavioral loyalty ("no loyalty"). This illustrates the importance of complementing relationship quality as a construct with behavioral data on loyalty. If not, retailers cannot make the distinction between true versus latent loyal customers and between spurious versus non-loyal customers. Such distinctions are of crucial importance, as retailing strategies should be defined 
differently depending upon the loyalty segment at hand. For example, while a retailer's strategy targeted at true loyal customers can be focused upon relationship maintenance, removing behavioral barriers such as opening up more stores can encourage latent loyal customers to purchase more. 


\section{REFERENCES}

Anderson, Eugene W. and Mary W. Sullivan (1990) 'The Antecedents and Consequences of Customer Satisfaction for Firms', Marketing Science, 12 (2): 125-143.

Ahtola, Olli T. (1984) 'Price as a 'Give' Component in an Exchange Theoretic Multicomponent Model', pp. 623-626 in Advances ill Consumer Research, vol 11, Thomas C. Kinnear, ed. Ann Arbor, MI: Association for Consumer Research.

Babakus, Emin and Gregory W. Boller (1992) 'An Empirical Assessment of the SERVQUAL Scale', Journal of Business Research, 24: 253-268.

Baumgartner, Hans and Christian Homburg (1996) ‘Applications of Structural Equation Modeling in Marketing and Consumer Research: A Review', International Journal of Research in Marketing, 13 (2): 139-161.

Bejou, David, Barry Wray, and Thomas N. Ingram (1996) 'Determinants of Relationship Quality: An Artificial Neural Network Analysis', Journal of Business Research, 36 (2): 137 143.

Blau, Peter (1964) Exchange and Power in Social Life. New York: John Wiley \& Sons.

Bolton, Ruth N. And James H. Drew (1991) ‘A Multistage Model of Customers’ Assessments of Service Quality and Value', Journal of Consumer Research, 17 (4): 375-384.

Boulding, William, Ajay Kalra, Richard Staelin, and Valarie A. Zeithaml (1993) 'A Dynamic Process Model of Service Quality: From Expectations to Behavioral Intentions', Journal of Marketing Research, 30 (February): 7-27. 
Boulding, William and Amna Kirmani (1993) ‘A Consumer-Side Experimental Examination of Signaling Theory: Do consumers Perceive Warranties as Signals of Quality?', Journal of Consumer Research, 20 (June): 111-123.

Churchill, Gilbert A., and Carol Surprenant (1982) 'An Investigation into the Determinants of Customer Satisfaction', Journal of Marketing Research, 16 (1): 64-73.

Colombo, Richard, and Weina Jiang (1999) 'A Stochastic RFM Model', Journal of Interactive Marketing, 13 (3): 2-12.

Corstjens, Marcel, and Rajiv Lal (2000) ‘Building Store Loyalty Through Store Brands', Journal of Marketing Research, 37 (August): 281-291.

Cronin, Joseph J. and Stephen A. Taylor (1992) 'Measuring Service Quality: A Reexamination and Extension', Journal of Marketing, 56 (3): 55-68.

Crosby, Lawrence A. and Nancy Stephens (1987) 'Effects of Relationship Marketing on Satisfaction, Retention, and Prices in the Life Insurance Industry', Journal of Marketing Research, 24 (November): 404-11.

, Kenneth R. Evans and Deborah Cowles (1990) 'Relationship Quality in Services Selling:

An Interpersonal Influence Perspective', Journal of Marketing, 54 (3): 68-81.

Dabholkar, Prathiba A., Dayle I. Thorpe and Joseph O. Rentz (1996) ‘A Measure of Service Quality for Retail Stores: Scale Development and Validation', Journal of the Academy of Marketing Science, 24 (1): 3-16.

Dawar, Niraj and Miklos Sarvary (1997) 'The Signaling Impact of Low Introductory Price on Perceived Quality and Trial', Marketing Letters, 8 (3): 251-259. 
De Wulf, Kristof, Gaby Odekerken-Schröder and Dawn Iacobucci (2001) 'Investments in Consumer Relationships: A Cross-Country and Cross-Industry Exploration', Journal of Marketing, 65 (4): 33-50

Dick, Alan S. and Kunal Basu (1994) 'Customer Loyalty: Toward an Integrated Conceptual Framework', Journal of the Academy of Marketing Science, 22(2): 99-113.

Dodds, William B., Kent B. Monroe, and Dhruv Grewal (1991) 'The Effects of Price, Brand, and Store Information on Buyers' Product Evaluations', Journal of Marketing Research, 28 (August): 307-319.

Dorsch, Michael J., Scott R. Swanson, and Scott W. Kelley (1998) 'The Role of Relationship Quality in the Stratification of Vendors as Perceived by Customers', Journal of the Academy of Marketing Science, 26(2): 128-142.

Dwyer, F. Robert, Paul Schurr and Sejo Oh (1987) 'Developping Buyer-Seller Relationships', Journal of Marketing, 51 (April): 11-27.

Evans, Kenneth R., Tim Christiansen, and James D. Gill (1996) 'The Impact of Social Influence and Role Expectations on Shopping Center Patronage Intentions', Journal of the Academy of Marketing Science, 24(3): 208-218.

Festinger, L. (1954) ‘A Theory of Social Comparison Processes’, Human Relations, 7: 117-140. Finn, Adam and Ujwal Kayande (1997) 'Reliability Assessment and Optimization of Marketing Measurement', Journal of Marketing Research, 36 (May): 262-275.

Fornell, Claes and David F. Larcker (1981) 'Evaluating Structural Equation Models with Unobservable Variables and Measurement Error', Journal of Retailing, 66 (Winter): 446469. 
Ganesan, Shankar (1994) 'Determinants of Long-Term Orientation in Buyer-Seller Relationships', Journal of Marketing, 58 (2): 1-19.

Garbarino, Ellen and Mark S. Johnson (1999) 'The Different Roles of Satisfaction, Trust and Commitment in Customer Relationships', Journal of Marketing, 63 (April): 70-87.

Garvin, David A. (1984) ‘What Does Product Quality Really Mean?’, Sloan Management Review, 26 (Fall): 25-43.

Gaski, John F. and Michael J. Etzel (1986) 'The Index of Consumer Sentiment toward Marketing', Journal of Marketing, 50 (July): 71-81.

Gwinner, Kevin P., Dwayne D. Gremler, and Mary Jo Bitner (1998) 'Relational Benefits in Services Industries: the Customer's Perspective', Journal of the Academy of Marketing Science, 26 (2): 101-114.

Hildebrandt, Lutz (1987) 'Consumer Retail Satisfaction in Rural Areas: A Reanalysis of Survey Data', Journal of Economic Psychology, 8 (1): 19-42.

Kirmani, Amna and Akshay R.Rao (2000) 'No Pain, No Gain: A Critical Review of the Literature on Signaling Unobservable Product Quality', Journal of Marketing, 64 (April): 6679.

Kirmani, Amna (1997) 'Advertising Repetition as a Signal of Quality: If It's Advertised so Often, Something must be Wrong', Journal of Advertising, 26 (3): 77-86.

Li, Zhan G. and Rajiv P. Dant (1997) ‘An Exploratory Study of Exclusive Dealing in Channel Relationships', Journal of the Academy of Marketing Science, 25 (3): 201-213.

McDaniel, S.W. and J.J. Burnett (1990) 'Consumer Religiosity and Retail Store Evaluative Criteria', Journal of the Academy of Marketing Science, 18 (2): 101-112. 
Metcalf, Lynn. E., Carl R. Frear, and R. Krishnan (1992) ‘Buyer-Seller Relationships: An Application of the IMP Interaction Model', European Journal of Research in Marketing, 14(5): 487-497.

Mittal, Banwari and Walfried M. Lassar (1996) 'The Role of Personalization in Service Encounters', Journal of Retailing, 72 (1): 95-109.

Monroe, Kent B. and R. Krishnan (1985) 'The Effect of Price on Subjective Product Evaluations', pp. 209-232 in Perceived Quality, J. Jacoby and J. Olsen, eds. Lexington MA: Lexington Books.

Parasuraman, A., Valarie A. Zeithaml \& Leonard L. Berry (1988) 'SERVQUAL: A MultipleItem Scale for Measuring Consumer Perceptions of Service Quality', Journal of Retailing, 64 (1): 12-37.

___ a and _ _ (1991) 'Refinement and Reassessment of the SERVQUAL Scale', Journal of Retailing, 67 (4): 420-450.

, __ and _ _ (1994) 'Reassessment of Expectations as a Comparison Standard in Measuring Service Quality: Implications for further Research', Journal of Marketing, 58 (January): 111-124.

Peterson, Robert A. (1995) 'Relationship Marketing and the Customer', Journal of the Academy of Marketing Science, 23(4): 278-281.

Pritchard, Mark P., Mark E. Havitz and Dennis R. Howard (1999) 'Analyzing the CommitmentLoyalty Link in Service Contexts', Journal of the Academy of Marketing Science, 27 (3): 6473.

Rao, Akshay R., Lu Qu and Robert W. Ruiekert (1999) ‘Signaling Unobservable Quality Through a Brand Ally', Journal of Marketing Research, 36 (May): 258-268. 
Rust, Roland T., Anthony J. Zahorik, and Timothy L. Keiningham (1995) 'Return on Quality (ROQ): Making Service Quality Financially Accountable', Journal of Marketing, 59 (April): $58-70$.

Smith, J. Brock (1998) 'Buyer-Seller Relationships: Bonds, Relationship Management, and SexType', Canadian Journal of Administrative Sciences, 15(1): 76-92.

Steenkamp, Jan-Benedict E.M. and Hans C.M. van Trijp (1991) 'The Use of LISREL in Validating Marketing Constructs', International Journal of Research Marketing, 8: 283-299.

Storbacka, Kaj, Tore Strandvik, and Christian Grönroos (1994) 'Managing Customer Relationships for Profit: The Dynamics of Relationship Quality', International Journal of Services Industry Management, 5 (5): 21-38.

Woodside, Arch G., Lisa L. Frey and Robert Timothy Daly (1989) 'Linking Service Quality, Customer Satisfaction, and Behavioral Intention', Journal of Health Care Marketing, 9 (4): $5-17$.

Yoo, C., J. Park, and D.J. MacInnis (1998) 'Effects of Store Characteristics and In-Store Emotional Experiences on Store Attitudes', Journal of Business Research, 42 (3): 253-263. 
Table 1: Means, Standard Deviations, and Correlations

\begin{tabular}{|c|c|c|c|c|c|c|c|c|c|c|c|c|c|c|c|c|c|c|c|}
\hline & \multicolumn{19}{|c|}{ Correlation matrix } \\
\hline & $\begin{array}{l}\text { Mean } \\
\text { (SD) }\end{array}$ & 1 & 2 & 3 & 4 & 5 & 6 & 7 & 8 & 9 & 10 & 11 & 12 & 13 & 14 & 15 & 16 & 17 & 18 \\
\hline 1. Product price & $\begin{array}{l}3.54 \\
(.67)\end{array}$ & 1.00 & & & & & & & & & & & & & & & & & \\
\hline 2. Product quality & $\begin{array}{l}4.12 \\
(.66)\end{array}$ &.$\underline{\underline{.44}}$ & 1.00 & & & & & & & & & & & & & & & & \\
\hline 3. Service quality & $\begin{array}{l}3.83 \\
(.48)\end{array}$ &.$\underline{\underline{.45}}$ &. .52 & 1.00 & & & & & & & & & & & & & & & \\
\hline 4. Reliability & $\begin{array}{l}3.82 \\
(.62)\end{array}$ & .42 & $\underline{\underline{.40}}$ & .79 & 1.00 & & & & & & & & & & & & & & \\
\hline 5. Responsiveness & $\begin{array}{l}3.80 \\
(.67)\end{array}$ & $\underline{.30}$ & $\underline{\underline{.48}}$ & .75 & $\underline{\underline{.42}}$ & 1.00 & & & & & & & & & & & & & \\
\hline 6. Assurance & $\begin{array}{l}3.80 \\
(.56)\end{array}$ & $\underline{.38}$ & $\underline{\underline{38}}$ & .84 & $\underline{\underline{6.64}}$ &.$\underline{.49}$ & 1.00 & & & & & & & & & & & & \\
\hline 7. Empathy & $\begin{array}{l}3.69 \\
(.65)\end{array}$ & .31 & $\underline{\underline{.35}}$ &.$\underline{\underline{.79}}$ & $\underline{\underline{.50}}$ & .54 &.$\underline{.58}$ & 1.00 & & & & & & & & & & & \\
\hline 8. Tangibles & $\begin{array}{l}4.02 \\
(.55)\end{array}$ & .37 & $\underline{\underline{4.45}}$ &.$\underline{\underline{.80}}$ & $\underline{\underline{.59}}$ & $\underline{\underline{4.47}}$ &.$\underline{\underline{69}}$ & $\underline{.50}$ & 1.00 & & & & & & & & & & \\
\hline 9. Direct mail & $\begin{array}{l}4.07 \\
(.66)\end{array}$ & $\underline{.31}$ & $\underline{\underline{.30}}$ & $\underline{\underline{.36}}$ & $\underline{\underline{.33}}$ & $\underline{\underline{.24}}$ &. .35 & $\underline{\underline{.23}}$ & $\underline{.30}$ & 1.00 & & & & & & & & & \\
\hline 10. Preferential treatment & $\begin{array}{l}2.63 \\
(.72)\end{array}$ & -.01 & -.08 & -.06 & .01 & -.13 & -.01 & -.08 & -.01 & .06 & 1.00 & & & & & & & & \\
\hline $\begin{array}{l}\text { 11. Interpersonal } \\
\text { communication }\end{array}$ & $\begin{array}{l}2.50 \\
(.77)\end{array}$ & .25 & .16 & .35 & .32 & .13 & $\underline{.36}$ & $\underline{.32}$ & .28 & .12 & $\underline{\underline{.33}}$ & 1.00 & & & & & & & \\
\hline 12. Tangible rewards & $\begin{array}{l}3.19 \\
(.89)\end{array}$ & .26 & $\underline{\underline{19}}$ & .37 & $\underline{\underline{.36}}$ & .17 &.$\underline{\underline{.36}}$ & $\underline{\underline{.26}}$ & $\underline{\underline{36}}$ & $\underline{\underline{.23}}$ &.$\underline{\underline{.39}}$ & $\underline{\underline{.28}}$ & 1.00 & & & & & & \\
\hline $\begin{array}{l}\text { 13. Perceived relationship } \\
\text { investment }\end{array}$ & $\begin{array}{l}3.30 \\
(.73)\end{array}$ &.$\underline{\underline{.26}}$ &.$\underline{\underline{.29}}$ & $\underline{.50}$ & $\underline{\underline{4.45}}$ & $\underline{\underline{.23}}$ & $\underline{\underline{45}}$ & $\underline{.44}$ & $\underline{\underline{46}}$ &.$\underline{.35}$ & $\underline{\underline{.27}}$ & $\underline{\underline{.53}}$ & $\underline{\underline{46}}$ & 1.00 & & & & & \\
\hline 14. Relationship quality & $\begin{array}{l}3.56 \\
(.53)\end{array}$ & .47 & $\underline{\underline{4.48}}$ & .74 & $\underline{\underline{.61}}$ & $\underline{\underline{4.47}}$ & .66 & .57 & $\underline{.63}$ &. .35 & .16 &. .52 & $\underline{\underline{.63}}$ & $\underline{\underline{.67}}$ & 1.00 & & & & \\
\hline $\begin{array}{l}\text { 15. Relationship } \\
\text { satisfaction }\end{array}$ & $\begin{array}{l}3.49 \\
(.63)\end{array}$ & .37 & $\underline{\underline{.37}}$ & .62 & $\underline{\underline{49}}$ & $\underline{\underline{.36}}$ & $\underline{.58}$ & $\underline{\underline{.51}}$ &. .54 &. .38 & .18 & $\underline{\underline{.57}}$ & $\underline{\underline{.54}}$ & $\underline{\underline{68}}$ & $\underline{\underline{85}}$ & 1.00 & & & \\
\hline 16. Trust & $\begin{array}{l}3.90 \\
(.51)\end{array}$ & $\underline{.43}$ & $\underline{\underline{47}}$ & .72 & $\underline{\underline{.60}}$ & $\underline{\underline{49}}$ & .63 &.$\underline{\underline{.56}}$ & $\underline{.60}$ & .32 & .06 & .37 & $\underline{\underline{.60}}$ & .50 & .83 & .63 & 1.00 & & \\
\hline $\begin{array}{l}\text { 17. Relationship } \\
\text { commitment }\end{array}$ & $\begin{array}{l}3.28 \\
(.72)\end{array}$ & $\underline{\underline{.40}}$ & $\underline{\underline{.38}}$ & $\underline{.56}$ & $\underline{\underline{49}}$ & $\underline{\underline{.38}}$ & $\underline{.48}$ & $\underline{\underline{.41}}$ & $\underline{\underline{.48}}$ &.$\underline{\underline{.21}}$ & .14 & $\underline{\underline{38}}$ & $\underline{\underline{48}}$ & $\underline{\underline{.52}}$ & $\underline{\underline{.86}}$ & $\underline{\underline{.54}}$ &. .57 & 1.00 & \\
\hline 18. Behavioral loyalty & $\begin{array}{c}41.4 \\
(31.99)\end{array}$ & .02 & .02 & .04 & .11 & .06 & -.02 & .02 & -.03 & .14 & .07 & .03 & -.03 & -.01 & .06 & .03 & .06 & .07 & 1.00 \\
\hline
\end{tabular}


Table 2: Measurement Model

\begin{tabular}{|c|c|c|}
\hline Constructs and related items & $\begin{array}{l}\text { Composite } \\
\text { reliability }\end{array}$ & $\begin{array}{c}\text { Percentage } \\
\text { of variance } \\
\text { extracted }\end{array}$ \\
\hline $\begin{array}{l}\text { Product price (Dodds, Monroe, and Grewal 1991) } \\
\text { The apparel sold by this store can be considered as a bargain } \\
\text { The price of the apparel sold by this store is acceptable } \\
\text { The price of the apparel sold by this store can be regarded as competitive }\end{array}$ & .95 & .87 \\
\hline $\begin{array}{l}\text { Product quality (Gaski and Etzel 1986) } \\
\text { The quality of most apparel that I buy at this store meets my expectations } \\
\text { I am satisfied with most apparel that I buy at this store }\end{array}$ & .94 & .87 \\
\hline $\begin{array}{l}\text { Service quality (Parasuraman, Zeithaml, and Berry 1988/1994) } \\
\text { 1. Reliability } \\
\text { When this store promises to do something by a certain time, it does so } \\
\text { When you have a problem, this store show a sincere interest in solving it } \\
\text { This store performs the service right the first time } \\
\text { This store provides its service at the time at promises to do so } \\
\text { 2. Responsiveness } \\
\text { Employees in this store cannot give you prompt service (reversed) } \\
\text { Employees in this store are always willing to help you } \\
\text { Employees in this store are often too busy to respond to your requests (reversed) } \\
\text { 3. Assurance } \\
\text { The behavior of employees in this store instills confidence in you } \\
\text { You feel safe in your transactions with this store } \\
\text { Employees in this store are consistently courteous with you } \\
\text { Employees in this store are well equipped to perform their tasks properly } \\
\text { 4. Empathy } \\
\text { This store does not give you individual attention (reversed) } \\
\text { This store does not have your best interests at heart (reversed) } \\
\text { Employees of this store do not understand your specific needs (reversed) } \\
\text { 5. Tangibles } \\
\text { This store has modern-looking equipment } \\
\text { This store's physical facilities are visually appealing } \\
\text { The store's employees are neat-appearing } \\
\text { The interior of this store is in line with the level of service delivered } \\
\text { The layout of this store enables customers to locate things easily } \\
\text { The layout of this store enables customers to wander around at ease } \\
\text { This store has clean, attractive, and accessible rooms (toilets and dressing rooms) }\end{array}$ & .96 & .83 \\
\hline $\begin{array}{l}\text { Direct mail (De Wulf, Odekerken-Schröder, and Iacobucci 2001) } \\
\text { This store often sends mailings to regular customers } \\
\text { This store keeps regular customers informed through mailings } \\
\text { This store often informs regular customers through brochures }\end{array}$ & .97 & .91 \\
\hline $\begin{array}{l}\text { Preferential treatment (De Wulf, Odekerken-Schröder, and Iacobucci 2001) } \\
\text { This store makes greater efforts for regular customers than for non-regular customers } \\
\text { This store offers better service to regular customers than to non-regular customers } \\
\text { This store does more for regular customers than for non-regular customers }\end{array}$ & .97 & .91 \\
\hline $\begin{array}{l}\text { Interpersonal communication (De Wulf, Odekerken-Schröder, and Iacobucci 2001) } \\
\text { This store takes the time to personally get to know regular customers } \\
\text { This store often holds personal conversations with regular customers } \\
\text { This store often inquires about the personal welfare of regular customers }\end{array}$ & .97 & .91 \\
\hline $\begin{array}{l}\text { Tangible rewards (De Wulf, Odekerken-Schröder, and Iacobucci 2001) } \\
\text { This store rewards regular customers for their patronage } \\
\text { This store offers regular customers something extra because they keep buying there } \\
\text { This store offers discounts to regular customers for their patronage }\end{array}$ & .97 & .92 \\
\hline
\end{tabular}




\begin{tabular}{|c|c|c|}
\hline \multicolumn{2}{|c|}{$\begin{array}{l}\text { Composite } \\
\text { reliability }\end{array}$} & $\begin{array}{l}\text { Percentage } \\
\text { of variance } \\
\text { extracted }\end{array}$ \\
\hline $\begin{array}{l}\text { Perceived relationship investment (De Wulf, Odekerken-Schröder, and Iacobucci 2001) } \\
\text { This store makes efforts to increase regular customer's loyalty } \\
\text { This store makes various efforts to improve its tie with regular customers } \\
\text { This store really cares about keeping regular customers }\end{array}$ & .96 & .88 \\
\hline $\begin{array}{l}\text { Relationship quality } \\
\text { 1. Relationship satisfaction (De Wulf, Odekerken-Schröder, and Iacobucci 2001) } \\
\text { As a regular customer, I have a high quality relationship with this store } \\
\text { I am happy with the efforts this store is making towards regular customers like me } \\
\text { I am satisfied with the relationship I have with this store } \\
\text { 2. Trust (De Wulf, Odekerken-Schröder, and Iacobucci 2001) } \\
\text { This store gives me a feeling of trust } \\
\text { I have trust in this store } \\
\text { This store gives me a trustworthy impression } \\
\text { 3. Relationship commitment (De Wulf, Odekerken-Schröder, and Iacobucci 2001) } \\
\text { I am willing 'to go the extra mile' to remain a customer of this store } \\
\text { I feel loyal towards this store } \\
\text { Even if this store would be more difficult to reach, I would still keep buying there }\end{array}$ & .91 & .78 \\
\hline
\end{tabular}


Table 3: Structural Model

\begin{tabular}{ll}
\hline Hypothesized path & Estimate (S.E.) \\
\hline $\mathrm{H}_{1}:$ Product price $\rightarrow$ perceived relationship investment $(-)$ & $-.05(.08)$ \\
$\mathrm{H}_{2}:$ Product quality $\rightarrow$ perceived relationship investment $(+)$ & $+.01(.07)$ \\
$\mathrm{H}_{3}:$ Service quality $\rightarrow$ perceived relationship investment $(+)$ & $+.43(.10)^{* *}$ \\
$\mathrm{H}_{4}:$ Direct mail $\rightarrow$ perceived relationship investment $(+)$ & $+.11(.06)^{*}$ \\
$\mathrm{H}_{5}:$ Preferential treatment $\rightarrow$ perceived relationship investment $(+)$ & $+.07(.07)$ \\
$\mathrm{H}_{6}:$ Interpersonal communication $\rightarrow$ perceived relationship investment $(+)$ & $+.20(.07)^{* *}$ \\
$\mathrm{H}_{7}:$ Tangible rewards $\rightarrow$ perceived relationship investment $(+)$ & $+.35(.09)^{* *}$ \\
$\mathrm{H}_{8}:$ Perceived relationship investment $\rightarrow$ relationship quality $(+)$ & $+.88(.15)^{* *}$ \\
$\mathrm{H}_{9}:$ Relationship quality $\rightarrow$ behavioral loyalty $(+)$ & $+.06(.08)$ \\
\hline Squared multiple correlations for structural equations & \\
\hline Perceived relationship investment & .70 \\
Relationship quality & .77 \\
Behavioral loyalty & .00 \\
\hline
\end{tabular}

$* * p<.01$ (one-sided)

$* p<.05$ (one-sided) 
Figure 1: Conceptual Model

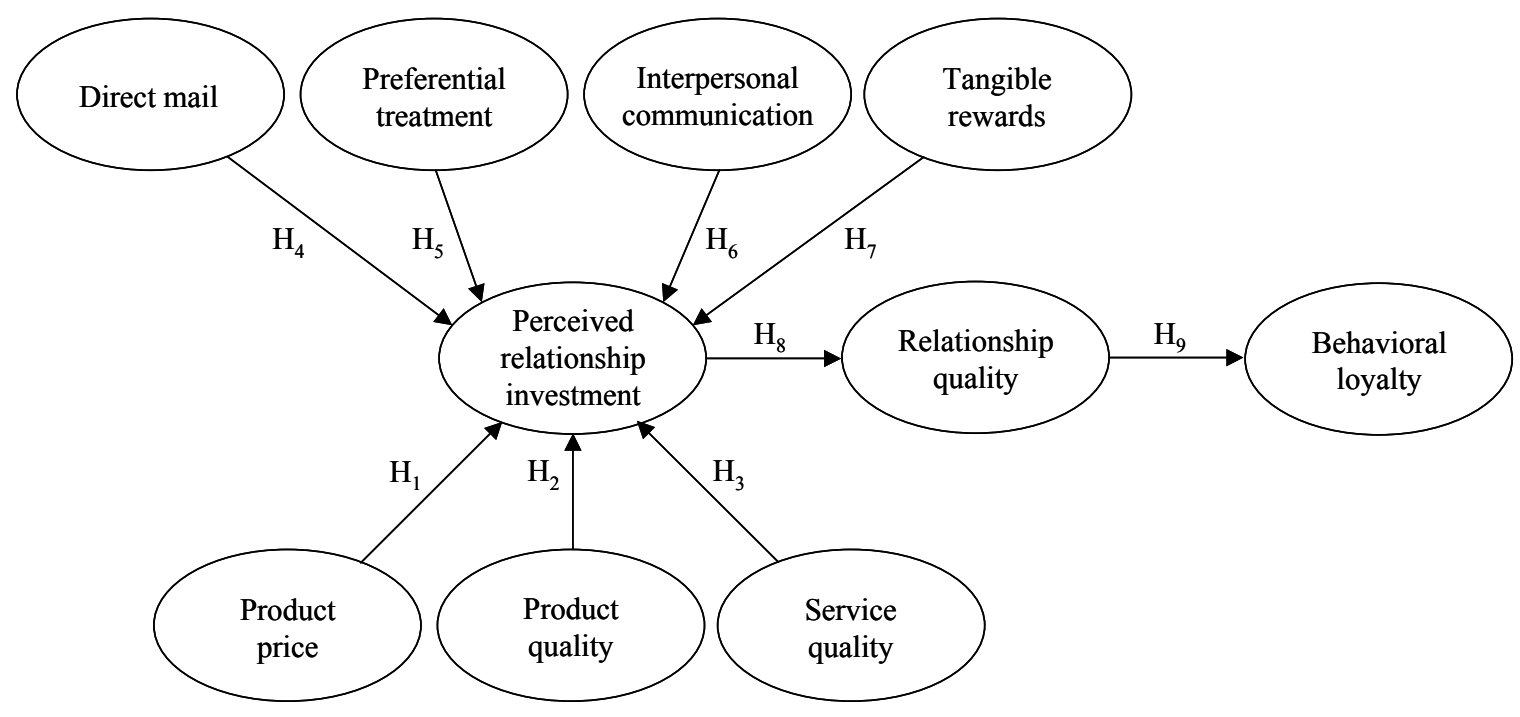

